\title{
Working Memory Structure in Children: Comparing Different Models During Childhood
}

\section{Estructura de la Memoria Operativa: Comparando diferentes modelos en la infancia}

\author{
Irene Injoque-Ricle, Juan Pablo Barreyro, \& Débora I. Burin \\ Consejo Nacional de Investigaciones Científicas y Técnicas (CONICET) - Facultad de Psicología, \\ Universidad de Buenos Aires - Argentina
}

Disponible online 31 de agosto de 2012

\begin{abstract}
Working Memory (WM) is an active memory system responsible for the temporary storage and concurrent processing of information. Different authors have considered WM as a complex but unitary system, whereas others have suggested that the system is multidimensional. In this line, the model developed by Baddeley and Hitch (1974) is one of the most well known; it proposes two modality-specific components - the phonological loop and the visuo-spatial sketchpad - and a supervisory executive system - the central executive. This paper contributes to the debate on WM structure by investigating three groups of children of different ages and assessing different models using confirmatory factor analysis. The Working Memory Assessment Battery Test (Alloway, 2007; Injoque-Ricle, Calero, Alloway \& Burin, 2011) was administered to 180 monolingual Spanish-speaking children. The three age groups consisted of 6-, 8-, and 11 -year-old children ( $\mathrm{n}=60$ participants per group). The results suggest that the WM structure is not uniform across the different age groups tested, showing progressive differentiation and specialization during childhood. This structure would appear to form between the ages of 6 and 8 years and become more complex as adolescence is approached.
\end{abstract}

Keywords: Working Memory; Confirmatory Factor Analysis; Children; AWMA.

La Memoria Operativa (MO) es un sistema de memoria activa responsable del almacenamiento temporal y procesamiento concurrente de información. Diferentes autores han considerado a la MO como un sistema complejo pero unitario, otros sugieren una estructura más compleja. Uno de los modelos más aceptados es el de Baddeley y Hitch (1974) que propone dos componentes de modalidad específica, el Bucle Fonológico y la Agenda Viso-Espacial, y un sistema ejecutivo supervisor, el Ejecutivo Central. El objetivo de este trabajo es contribuir al debate de la estructura de la $\mathrm{MO}$ en tres grupos de edades de niños, evaluando diferentes modelos, a través de un análisis factorial confirmatorio. Se administró la Batería Automatizada de Memoria Operativa (Alloway, 2007; Injoque-Ricle, Calero, Alloway \& Burin, 2011) a 180 niños de habla española, distribuidos en tres grupos de edades (60 sujetos cada uno) de 6, 8 y 11 años. Los resultados sugieren que la estructura de la MO no sería uniforme entre los grupos evaluados, mostrando una diferenciación y especialización a lo largo de la infancia. Entre los 6 y los 8 años comienza a observarse una estructura y se complejiza hacia la adolescencia.

Palabras clave: Memoria Operativa; Análisis Factorial Confirmatorio; Niños; AWMA.

Correspondence concerning this article should be addressed to: Dra. Irene Injoque-Ricle. Instituto de Investigaciones, Facultad de Psicología, Universidad de Buenos Aires. Av. Independencia $30653^{\circ}$ Piso, Of. 13, (C1425AAM), Ciudad de Buenos Aires, Argentina. E-mail: iinjoque@psi.uba.ar. Authors’ E-mails: Dr. Juan Pablo Barreyro: jbarreyro@psi.uba.ar. Dra. Débora I. Burin: dburin@psi.uba.ar This research was supported by the Consejo Nacional de Investigaciones Científicas y Técnicas (CONICET; Res. № 258/06 and Res. º 3100/08) and by the Secretaría de Ciencia y Técnica, Universidad de Buenos Aires (SECyT; UBACyT P016).

The Automated Working Memory Assessment battery was translated and reproduced by Permission. Copyright (C) 2007 by Harcourt Assessment. Spanish Translation copyright (C) 2007 by Harcourt Assessment. All rights reserved. 
In the last decades there has been an increasing interest on Working Memory (WM), its neural substrate (e.g. Conway, Moore, \& Kane, 2009), its development (e.g. Hitch, Towse, \& Hutton, 2001; Hulme, Thomson, Muir, \& Lawrence, 1984; Luciana, Conklin, Hooper, \& Yarger, 2005), and its relation with different cognitive functions such as language and vocabulary acquisition (e.g. Adams \& Gathercole, 2000; Baddeley, Gathercole \& Papagno, 1998; Gathercole \& Baddeley, 1989, 1990; Gathercole, Willis, Emslie \& Baddeley, 1992), reading comprehension (e.g. Cain, Bryan \& Oakhill, 2004; Daneman \& Carpenter, 1980; Friedman \& Mikaye, 2004; Just \& Carpenter, 1992; Leather \& Henry, 1994), arithmetic skills (e.g. Bull \& Scerif, 2001; Fürst \& Hitch, 2000; Logie, Gilhooly,\& Wynn, 1994; Reuhkala, 2001), planning (e.g. Owen, Doyon, Petrides \& Evans, 1996; Phillips, Wynn, Gilhooly, Della Sala \& Logie, 1999), inhibition (e.g. Conway \& Engle, 1994; Rosen \& Engle, 1996; Redick, Heitz \& Engle, 2007; Robert, Borella, Fagot, Lecerf \& de Ribaupierre, 2009), impulsivity (e.g. Hinson, Jameson \& Whitney, 2003), and intelligence (Ackerman, Beier \& Boyle, 2005; Alloway \& Chiara Passolunghi, 2011; Colom, Abad, Quiroga, Shih \& Flores-Mendoza, 2008; Colom, Flores-Mendoza \& Rebollo, 2003; Engel, Conway \& Gathercole, 2010; Kyllonen \& Christal, 1990; Schmiedek, Oberauer, Wilhelm, Süß \& Wittmann, 2007; Süb, Oberauer, Wittmann, Wilhelm \& Schulze, 2002; Swanson, 2008), among others. The study of WM and its relationship with so many cognitive and behavioral skills at different ages shows its importance in everyday abilities. WM is an active memory system responsible for temporary storage and concurrent processing of information (Baddeley, 1986, 2007; Baddeley \& Hitch, 1974). It involves "the control, regulation, and active maintenance of task-relevant information in the service of complex cognition" (Shah \& Miyake, 1999, p. 450). WM is assessed by tasks that require maintenance of a limited amount of information (e.g., letters, numbers, words, non-word, figures) during a short period of time. If the tasks requires immediate serial recall it is usually called simple span or short term memory task, and if it involves concurrent processing or double task it's called complex span or working memory task (Unsworth, Redick, Heitz, Broadway \& Engle, 2009).

Different authors have considered WM as a complex but unitary system (e.g. Anderson, Reder \& Lebiere, 1996 ; Colom et al., 2003; Conway, Cowan, Bunting, Therriault \& Minkoff, 2002; Kane, Poole, Tuholski \& Engle, 2006). According to this approach, individual differences in WM are explained by variations in resources, the amount of activation available for storage and concurrent processing (Colom et al., 2003; Daneman \& Carpenter, 1980; Daneman \& Tardif, 1987; Just \& Carpenter, 1992; Kyllonen \& Christal, 1990). For some authors this capacity refers to a pool of attentional or executive resources (Conway et al., 2002; Conway \& Engle, 1994; Engle, Tuholski, Laughlin \& Conway, 1999; Kane et al., 2006). For example:
When we use the term working memory capacity, we refer to the attentional processes that allow for goal-directed behavior by maintaining relevant information in an active, easily accessible state outside of conscious focus, or to retrieve that information from inactive memory, under conditions of interference, distraction, or conflict (Kane, Conway, Hambrick \& Engle, 2007, p. 23).

Even when factor analysis has shown two different components in WM, a short term maintenance one and another for long term memory retrieval (Engle \& Kane, 2004; Unsworth \& Engle, 2007; Unsworth et al., 2009), or a short term memory factor and a WM one (Conway et al., 2002; Engle et al., 1999; Kane et al., 2004; Oberauer, Süb, Schulze, Wilhelm \& Wittmann, 2000; Süb et al., 2002), this research perspective has considered that due to the great amount of shared variance between the tests and their high correlations with different measures of cognitive abilities, the unitary model is the most plausible.

A second line of research suggests a fractioning within WM. One of the most accepted models is the one developed by Baddeley and Hitch (Baddeley, 1986, 1999a, 2007; Baddeley \& Hitch, 1974). According to this model, WM has two modality specific components, the phonological loop (PL), for the maintenance of verbal material, and the visuo-spatial sketchpad (VSSP) for the maintenance of visuo-spatial information; and a supervisory executive system, the central executive (CE), amodal and devoid of storage resources. The CE is a flexible system responsible for the control and regulation of the two slave systems (Baddeley, 1999a, 1999b, 2007; Baddeley \& Logie, 1999; Gathercole, Pickering, Ambridge \& Wearing, 2004). The most recent version of the model includes a third subsystem: the Episodic Buffer. This subsystem uses multidimensional codes to form an episodic representation. Due to this integration it works as an interface between different subsystems (Baddeley, 2000). This new component doesn't have the same empirical support than the original ones (Alloway, Gathercole, Willis \& Adams, 2004; Repovs \& Baddeley, 2006), so most WM research is based on the original model.

Another line of research has studied maintenance in the modal stores, and maintenance plus concurrent processing separately, sometimes referred as short-term and working memory, respectively (e.g. Baddeley, 1992, 2007; Conway et al., 2002; Engle et al., 1999; Gathercole \& Baddeley, 1989; Gathercole \& Hitch, 1993; Papagno \& Vallar, 1992; Swanson \& Howell, 2001; Tillman, Nyberg \& Bohlin, 2008). Verbal information storage in the PL is assessed as verbal short term memory (VSTM), and the capacity to process verbal information while storing in the PL, is termed verbal working memory (VWM). The same happens when the information modality is visuospatial: visuo-spatial short term memory (VSSTM) or visuospatial working memory (VSWM) is assessed. Within VSWM a subdivision between visual WM and spatial WM (Baddeley \& Logie, 1999; Logie, 1995; Logie \& Pearson, 1997) has been suggested. 
This debate has inspired several studies about the fractioning and development of WM in children. Chua and Maybery (1999) administered a verbal short term span task, a spatial one, and simple verbal and spatial processing speed tasks (speed of articulation, speed of tapping, and two simple search tasks), to a sample of school-aged children. Since partial correlation and regression analyses showed that age, articulation, and speed contributed to around ninety percent of the variance in verbal and spatial spans, regardless of modality, they concluded that a common source of development sustained WM growth. Further analyses of timing-of-recall in the spatial span task promoted the view that a common process underlies WM development, whereas other processes or structures would be age-unrelated. On the other hand, with a different approach, Gathercole et al. (2004) administered 9 tasks -three verbal storage tests, three visuo-spatial storage tests, and three processing and storage verbal tests- in four age groups: 6-7 years, 8-9 years, 10-12 years, and 13-15 years, to test two WM models. The first one was a two factor model, in which one factor included all six verbal tasks, and the second factor had the visuo-spatial tasks. The second model corresponded with Baddeley and Hitch original model (1974), but the factor that represented the CE only included verbal tasks. They found that the model that had better fit indexes in confirmatory factor analyses was the three factor model for all age groups. Alloway, Gathercole and Pickering (2006) administered the Automated Working Memory Assessment Battery (Alloway, Gathercole \& Pickering, 2004) -three VSTM, three VWM, three VSSTM, and three VSWM- to four age groups (4-6 years, 7-8 years, and 9-11 years). Seven models were compared using Confirmatory Factor Analysis. One of these models comprised three factors, and proposed that the storage factors included both storage tests as well as processing tests, and that the processing tests were also included in a third processing factor. Results showed that this model had better fit indexes for the two oldest groups as well as for the whole sample. For the 4-6 years old group there were no significant differences between this new model and the classical three factors model which represented Baddeley and Hitch's classic model.

So then, WM seems to acquire a more complex structure along childhood, but the evidence is scarce and presents mixed results, such as whether it conforms to the classic Baddeley and Hitch's model. The aim of this study is to contribute to the debate of WM structure in children, assessing if WM structure changes across childhood and if it does, to explore how it changes. Following the different theoretic approaches mentioned above, four models were tested using confirmatory factor analysis: 1) WM as an unitary model, with no subcomponents (Model 1); 2) WM composed by two subsystems, one verbal and one visuo-spatial (Model 2); 3) WM divided in three factors, a verbal low executive demand subsystem, a visuo-spatial low executive demand subsystem, and domain-unspecific high executive demand subsystem (Model 3); and 4) WM com- posed by four factors, two modality specific storage systems, one verbal and one visuo-spatial, and two processing factors, one verbal and one visuo-spatial (Model 4).

\section{Participants \\ Method \\ One-hundred and eighty monolingual Spanish-speaking} children (103 female -57.2\%-, and 77 male) within a purposive sample participated on the study. They belonged to three age groups ( $n=60$ ss. each): 6-, 8-, and 11-years old. The younger group had a mean age of 80.04 months $(S D=3.26)$. The 8 -years old group had a mean age of 102.12 months $(S D=3.24)$. The older group had a mean age of 140.07 months $(S D=2.89)$. Distribution of gender by group is shown in Table 1.

Table 1

Age and gender distribution

\begin{tabular}{lcccccccc}
\hline & \multicolumn{1}{c}{ Age } & \multicolumn{3}{c}{ All } \\
\cline { 2 - 10 } & \multicolumn{2}{c}{6} & \multicolumn{2}{c}{8} & \multicolumn{1}{c}{11} & \multicolumn{2}{c}{ A } & $\%$ \\
\hline Female & 25 & 41.7 & 35 & 58.3 & 43 & 71.7 & 103 & 57.22 \\
Male & 35 & 58.3 & 25 & 41.7 & 17 & 28.3 & 77 & 42.78 \\
\hline Total & 60 & 100 & 60 & 100 & 60 & 100 & 180 & 100 \\
\hline
\end{tabular}

The participants represent a sample of convenience. Children attended, and were tested at, two middle-class public elementary-level schools in the city of Buenos Aires.

Parents were invited to an informative meeting about the study, after which informed consent was solicited in order to allow their children to participate. A written devolution was provided for each child's parents.

Possible participants with a diagnosed psychiatric or neurological condition, language or hearing impairment, or a history of academic failure (repeating course) were excluded from the study. This information was provided by the school registers.

\section{Materials}

Automated Working Memory Assessment battery test (AWMA; Alloway, 2007; Injoque-Ricle et al., 2011). This battery is composed by twelve WM tasks and allows to assess all aspects of this memory system. The battery is fully automated, computer-administered. Instructions, as well as verbal stimuli are presented aurally, thereby excluding reading requirements. It includes three low executive demand verbal storage tasks (Digit recall, Word recall, and Nonword recall), three low executive demand visuo-spatial storage tasks: (Dot Matrix, Block recall, and Mazes Memory), three high executive demand verbal processing tasks (Listening recall, Counting recall, and Backward digit recall), and three high executive demand visuospatial processing ones (Odd one out, Mister X, and Spatial Span). In Digit recall, Word recall, and Nonword recall, the child has to recall a sequence of numbers, words or non-words, respectively, in the correct order. In Dot matrix, a sequence of red dots appears on a white matrix and the child has to point 
the squares of the matrix on which each dot appeared, in the exact same order. Block recall has the same procedure than Dot Matrix; the child sees on the computer screen a board with nine cubes, located randomly, then some of the cubes are touched by an examiner, and the child has to reproduce the touches in correct order. In Mazes memory, the child sees a two-dimensional maze with a path drawn on it, and immediately has to reproduce the path, tracing it with his or her finger. In Listening recall, the child listens to a series of short sentences and has to decide whether they are true or false, and then has to recall the last word of each sentence on the exact order. Counting recall shows a series of dots and arrows appears on the computer screen and the child has to count aloud one by one all the dots, and finally, recall the total number of dots that appear on each trial, in correct order. Backward digit recall presents sequences of numbers and the child has to recall them in reverse order. Odd one out, shows sets of three shapes on the computer screen, two are the same and the third one is different. The child has to indicate which one is the odd one out, and after a certain amount of sets are presented, they have to point to the place in which the odd figure was presented, in the exact order. In Mister $X$, sets of two stick people figures are presented, one with a yellow hat and the other with a blue one, and both with a red dot in one of their hands. The figure with the blue hat can appear rotated in six possible positions. The child has to say whether they have the dot in the same hand or in a different one, and then, in a picture with six compass points, has to point the location of the red dot in sequence. Spatial span shows sets of two arbitrary shapes, one with a red dot on top of it, and one of them can be rotated in three possible positions. First, child has to say if the shape with the red dot is the same or the opposite than the one without the dot, and then, has to point in sequence the location of the dot in a three compass points. Each AWMA task has increasing difficulty levels, with six items each. When the child fails at least in three items of the same level, the task is discontinued and the next one is administered.

\section{Procedure}

Children completed the AWMA in an individual session lasting approximately 40 minutes, in a quiet office at their school. The order of the tasks was the standard postulated by the authors of the test: Digit recall, Dot matrix, Listening recall, Odd one out, Word recall, Mazes memory, Counting recall, Mister x, Nonword recall, Block recall, Backward digit recall, and Spatial recall.

\section{Data analysis}

In order to assess the structural organization of WM in the three group ages a confirmatory factor analysis (CFA) was conducted using the AMOS c.5.0 software (Arbuckle, 2003). CFA is a statistical method used to test the goodness of fit of a theoretical model to the empirical data (Arbuckle, 2003; Hair, Anderson, Tatham, \& Black, 1998). Analyses were carried out using the maximum likelihood estimation, focusing on the factor score weights, reliability and model fit indexes for each one of the tested models (Arbuckle, 2003; Harrington, 2008).

The model fit indexes used were: Chi Squared $\left(\chi^{2}\right)$, Comparative Fix Index (CFI), Tucker-Lewis Index (TLI) and Root Mean Squared Error of Approximation (RMSEA) (Bollen, 1990; Kline, 1998). Chi Squared is a goodness-of-fit measure base on the comparison between the covariance matrix of a proposed model and the covariance matrix of the data. It shouldn't be significant if there is a good model fit (Hu \& Bentler, 1999). CFI compares the fit of the existing with the fit of a null model which assumes the latent variables in the model are uncorrelated. Its value has to be at least 90 (Schumacker \& Lomax, 1996). TLI is one of the goodness-of-fit measures less affected by the sample size because it doesn't include the degrees of freedom of none of the models in its equation. By convention, values equal or over to .90 indicate a good fit of the model (Hair et al., 1998). RMSEA is a measure of approximate fit with an attempt to remove the effects produced by the degrees of freedom and the sample size. The cutoff of a good model fit is suggested to be equal or lower to .06 (Hu \& Bentler, 1999).

Even if the number of subjects by age group of this study (n:p) might be considered small, according to Cattell (1978), a ratio of $n: p$ between 3 to 6 is accepted, and following Gorsuch (1983), if $n: p=5$ this analysis can be conducted.

Pearson's correlation analysis among all AWMA subtests was conducted on the complete sample and within each age group to assess the relationships between the tasks.

\section{Results}

Table 2 showed the descriptive statistics for all the AWMA tasks. When normality wasn't reached the scores were transformed to its natural logarithm. For the 6-year old group the transformed variables were: Counting recall, Backward digit recall, and Odd one out. For the 8-years-old group: Listening recall and Mister X. For the 11-years old group, Digit recall, Word recall, Mazes memory, Listening recall, and Backward digit recall were transformed. And in the general sample, Digit recall, Mazes memory, Listening recall, Backward digit recall, and Mister $X$ required normalization.

Pearson's correlation analysis with the complete sample $(N$ $=180$ ) shows that all tasks have a positive significant correlation between each other (Table 3).

At 6-years old, the following correlations were observed. When analyzing verbal low executive demand tasks (Digit recall, Word recall, and Nonword recall), significant correlation is only observed between Digit recall and Nonword recall $(r=.27, p<.05)$, and between Digit recall and some of the rest of the AWMA tasks (see Table 3 ). When analyzing correlations within the low executive demand tasks (Dot matrix, Block recall, and Mazes memory), a high significant correction between Dot matrix and Block recall $(r=.77, p<.01)$, was observed, and a significant but low correlation was found 
WORKING MEMORY STRUCTURE IN CHILDREN

Table 2

Descriptive statistics for AWMA subtests

\begin{tabular}{|c|c|c|c|c|c|c|c|c|c|c|c|c|c|c|c|c|}
\hline & \multicolumn{4}{|c|}{6 -years old } & \multicolumn{4}{|c|}{8 -years old } & \multicolumn{4}{|c|}{ 11-years old } & \multicolumn{4}{|c|}{ All } \\
\hline & $M$ & $S D$ & $S k$ & $K$ & $M$ & $S D$ & $S k$ & $K$ & $M$ & $S D$ & $S k$ & $K$ & $M$ & $S D$ & $S k$ & $K$ \\
\hline Digit Recall & 19.87 & 3.36 & 0.298 & -0.524 & 23.33 & 3.12 & 0.232 & -0.503 & 26.87 & 4.17 & 0.664 & 0.471 & 23.36 & 4.568 & .452 & .419 \\
\hline Word Recall & 14.78 & 3.74 & 0.039 & -0.507 & 17.87 & 4.15 & -0.193 & -0.770 & 19.25 & 4.85 & -0.969 & 3.209 & 17.30 & 4.639 & -.218 & .299 \\
\hline Nonword Recall & 8.15 & 2.87 & -0.107 & -0.860 & 8.87 & 3.16 & -0.074 & 0.005 & 11.22 & 3.66 & 0.176 & -0.134 & 9.41 & 3.485 & .254 & .099 \\
\hline Dot Matrix & 15.83 & 4.34 & 0.193 & 0.560 & 20.77 & 4.63 & 0.171 & 0.106 & 24.95 & 4.70 & 0.128 & -0.035 & 20.52 & 5.874 & .121 & -.230 \\
\hline Block Recall & 14.45 & 4.91 & 0.278 & -0.202 & 19.93 & 4.46 & 0.156 & 0.185 & 25.47 & 4.16 & 0.029 & 0.817 & 19.95 & 6.370 & -.082 & -.444 \\
\hline Mazes Memory & 10.38 & 6.51 & -0.071 & -1.012 & 20.02 & 4.66 & -0.183 & -0.353 & 25.55 & 4.30 & -1.305 & 5.271 & 18.65 & 8.166 & -.584 & -.370 \\
\hline Listening Recall & 3.48 & 3.22 & 0.281 & -0.968 & 8.10 & 3.70 & 0.815 & 0.375 & 11.83 & 4.06 & 0.686 & 0.626 & 7.81 & 5.011 & .412 & .058 \\
\hline Counting Recall & 11.27 & 4.21 & 0.863 & 1.041 & 15.55 & 3.99 & 0.137 & 0.053 & 19.77 & 4.53 & -0.289 & 0.075 & 15.53 & 5.476 & .160 & -.597 \\
\hline Back. D. Recall & 6.63 & 3.04 & 0.306 & 1.870 & 9.28 & 2.82 & 0.369 & 0.085 & 14.03 & 4.07 & 0.818 & 1.982 & 9.98 & 4.532 & .681 & 1.186 \\
\hline Mister X & 4.57 & 3.02 & 0.409 & 0.514 & 7.05 & 3.40 & 1.594 & 4.310 & 11.27 & 4.62 & 0.291 & -0.051 & 7.63 & 4.644 & .827 & .686 \\
\hline Spatial Span & 9.05 & 4.96 & 0.618 & -0.008 & 12.48 & 5.57 & -0.422 & -0.582 & 18.50 & 4.30 & -0.360 & 0.700 & 13.34 & 6.306 & -.104 & -.799 \\
\hline
\end{tabular}

Note. M: Mean; SD: Standard Deviation; Sk: Skewness; K: Kurtosis

between Dot matrix and Mazes memory $(r=.25, p<.05)$. With the rest of the tasks correlations were also found (see Table 3 ). Within verbal high executive demand tasks (Listening recall, Counting recall, and Backward digit recall), only a correlation between Counting recall and Backward digit recall was found $(r=.30, p<.05)$. Regarding the rest of the other AWMA tasks, some correlations were also found (see Table 3). Finally, within the visuo-spatial high executive demand tasks (Odd one out, $M r . X$, and Spatial span), significant correlations were observed between Odd one out and Spatial span $(r=.38, p<.01)$ and between Mr. X and Spatial span $(r=.27, p<.05)$ (Table 3).
At the 8-years old group, within the verbal low executive demand tasks only a significant correlation between Digit recall and Nonword recall was observed $(r=.43, p<.01)$. Significant correlations with other AWMA tasks were also found (see Table 4). When analyzing the associations between the visuo-spatial low executive demand tasks, Dot matrix had significant correlations with Block recall $(r=.69, p<.01)$, and with Mazes memory $(r=.36, p<.01)$, and Block recall with Mazes memory $(r=.36, p<.01)$. This tasks also have significant correlations with other tasks of the WM battery (see Table 4). Regarding the verbal high executive demand tasks, Counting recall showed

Table 3

Pearson's correlations among AWMA subtests for the complete sample and for the 6-years old group

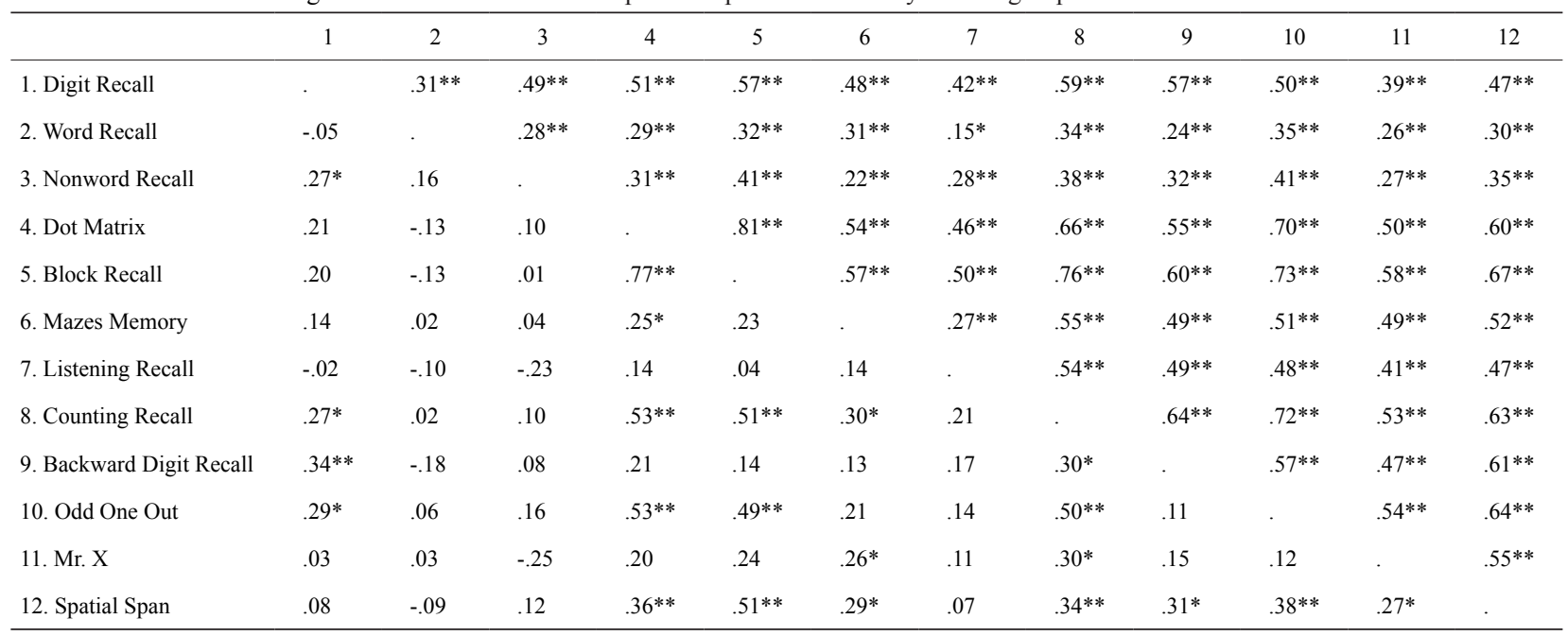

Note. $\mathrm{N}=180 ; 6$-years old $n=60$

Complete sample correlations are shown above the diagonal. 6-years old group correlation are shown below the diagonal.

$* * \mathrm{p}<.01 ; * \mathrm{p}<.05$ 
IRENE INJOQUE-RICLE, JUAN PABLO BARREYRO, DÉBORA I. BURIN

Table 4

Pearson's correlations among AWMA subtests for the 8-years old group and the 11-years old group

\begin{tabular}{|c|c|c|c|c|c|c|c|c|c|c|c|c|}
\hline & 1 & 2 & 3 & 4 & 5 & 6 & 7 & 8 & 9 & 10 & 11 & 12 \\
\hline 1. Digit Recall & . & .10 & $.43^{* *}$ & .08 & .20 & .06 & .20 & $.26^{*}$ & .11 & -.04 & .11 & .22 \\
\hline 2. Word Recall & .18 & . & .20 & .22 & .18 & .19 & .01 & .13 & .07 & .25 & .12 & .12 \\
\hline 3. Nonword Recall & $.44 * *$ & .18 & . & .13 & $.37^{* *}$ & .07 & $.28 *$ & $.31^{*}$ & .05 & .23 & .22 & .18 \\
\hline 4. Dot Matrix & .25 & .04 & .12 & . & $.69^{* *}$ & $.36 * *$ & $.30^{*}$ & $.64 * *$ & .23 & $.53 * *$ & $.34 * *$ & $.34 * *$ \\
\hline 5. Block Recall & $.28 *$ & .13 & $.32 *$ & $.54 * *$ & . & $.36^{* *}$ & $.41 * *$ & $.70^{* *}$ & .24 & $.54 * *$ & $.49 * *$ & $.32 *$ \\
\hline 6. Mazes Memory & .24 & .15 & -.07 & .25 & .24 & . & .05 & $.36^{* *}$ & $.37 * *$ & $.47 * *$ & $.44 * *$ & $.44 * *$ \\
\hline 7. Listening Recall & $.35^{* *}$ & -.10 & $.36^{* *}$ & .15 & $.28^{*}$ & .10 & . & $.45^{* *}$ & .20 & $.35 * *$ & .24 & $.38 * *$ \\
\hline 8. Counting Recall & $.40 * *$ & .20 & .23 & .18 & $.50^{* *}$ & $.29 *$ & $.37 * *$ & . & $.39 * *$ & $.61 * *$ & $.35^{* *}$ & $.45 * *$ \\
\hline 9. Backward Digit Recall & $.34 * *$ & .08 & .23 & $.32 *$ & $.50^{* *}$ & .16 & $.43^{* *}$ & $.52^{* *}$ & . & $.33^{*}$ & .19 & $.34 * *$ \\
\hline 10. Odd One Out & $.30^{*}$ & .19 & $.36^{* *}$ & $.54 * *$ & $.61^{* *}$ & $.26^{*}$ & $.28^{*}$ & $.55^{* *}$ & $.56^{* *}$ & . & $.41 * *$ & $.29^{*}$ \\
\hline 11. Mr. X & .15 & .10 & $.33^{*}$ & .23 & $.33^{*}$ & .20 & .22 & $.27^{*}$ & $.28^{*}$ & $.50^{* *}$ & . & $.41^{* *}$ \\
\hline 12. Spatial Span & .14 & .12 & .18 & $.34 * *$ & $.48 * *$ & .13 & .23 & $.44 * *$ & $.47 * *$ & $.65^{* *}$ & $.36^{* *}$ & \\
\hline
\end{tabular}

Note. 8-years old group: $n=60 ; 11$-years old group: $n=60$

8 -years old group correlations are shown above the diagonal. 11-years old group correlations are shown below the diagonal.

$* * \mathrm{p}<.01 ; * \mathrm{p}<.05$

significant correlations with Listening recall $(r=.45, p<.01)$ and Backward digit recall $(r=.39, p<.01)$. Significant correlations with the rest of the tasks are shown in Table 4. Finally, within the visuo-spatial high executive demand tasks, all tasks showed significant correlations with each other, and also with other tasks from the battery (Table 4).

At 11-years old, within the verbal low executive demand tasks, only a significant correlation between Digit recall and Nonword recall $(r=.44, p<.01)$ was found, with the exception of the correlations found with the rest of the AWMA tasks (see Table 4). Regarding the visuo-spatial low executive demand tasks, also one significant correlation was found

within this task group, and was between Dot matrix and Block recall $(r=.54, p<.01)$. For the significant correlations found with the other AWMA tasks see Table 4 . When observing the associations within the verbal high executive demand tasks, Listening recall showed a significant correlation with Counting recall $(r=.37, p<.01)$, and Backward digit recall $(r=$ $.43, p<.01$ ), and Counting recall with Backward digit recall $(r=.52, p<.01)$. Significant correlations with the rest of the WM tasks were also found and are shown in Table 4. Regarding the visuo-spatial high executive demand tasks, all have significant correlations between each other, and with other WM tasks (Table 4).

Table 5

Goodness-of-Fit statistics for the different models for each group

\begin{tabular}{|c|c|c|c|c|c|c|c|}
\hline & Age & $\chi^{2}$ & d.f. & Sig. & $C F I$ & $T L I$ & RMSEA \\
\hline \multirow[t]{4}{*}{ Model 1} & 6 & 85.564 & 54 & .004 & .786 & .738 & .100 \\
\hline & 8 & 71.234 & 54 & .058 & .914 & .895 & .074 \\
\hline & 11 & 68.162 & 54 & .093 & .926 & .909 & .067 \\
\hline & All & 101.860 & 54 & .000 & .959 & .950 & .070 \\
\hline \multirow[t]{3}{*}{ Model 2} & 6 & 71.290 & 53 & .048 & .876 & .845 & .076 \\
\hline & 8 & 69.221 & 53 & .067 & .919 & .899 & .072 \\
\hline & 11 & 58.103 & 53 & .293 & .973 & .967 & .040 \\
\hline \multirow[t]{4}{*}{ Model 3} & 6 & 73.297 & 51 & .022 & .849 & .804 & .086 \\
\hline & 8 & 61.186 & 51 & .155 & .949 & .934 & .058 \\
\hline & 11 & 56.728 & 51 & .270 & .970 & .961 & .044 \\
\hline & All & 67.413 & 51 & .062 & .986 & .982 & .042 \\
\hline \multirow[t]{3}{*}{ Model 4} & 6 & 66.265 & 48 & .041 & .876 & .829 & .080 \\
\hline & 8 & 60.253 & 48 & .110 & .939 & .916 & .066 \\
\hline & 11 & 46.786 & 48 & .523 & 1.000 & 1.000 & .000 \\
\hline \multirow[t]{4}{*}{ Model 5} & 6 & 82.769 & 53 & .006 & .796 & .748 & .098 \\
\hline & 8 & 62.926 & 53 & .165 & .951 & .938 & .056 \\
\hline & 11 & 60.746 & 53 & .217 & .959 & .949 & .050 \\
\hline & All & 85.113 & 53 & .003 & .973 & .966 & .058 \\
\hline
\end{tabular}


At 6-years old CFA showed that none of the proposed model adjusted to the data. Table 5 shows the models fit indexes for this age group.

In the 8 years old subsample, the model that had the best fit indexes was the three factor model $\left(\chi^{2}=61.186, p=\right.$ $.155 ; C F I=.949 ; T L I=.934 ; R M S E A=.058)$. Despite the absence of significant differences between the three and four factor model, $\left(\Delta \chi^{2}=0.993, p=.80\right)$, the model fit indexes for latter $\left(\chi^{2}=60.253, p=.110 ; C F I=.939 ; T L I=.916 ; R M S E A\right.$ $=.066)$ weren't as good as those for the three factor. Table 3 shows the model fit indexes for this age group. The factor score weight values found are shown in Figure 1a. Regarding correlations among factors, significant and positive correlations were only found between Factor 2 and Factor 3 ( $r=$ $.935, p=.003)$. Due to the high correlation between Factor 2 and 3, a new model was tested in which both factors were turned into one (Figure 1b). On this new two factor model, one factor grouped the three verbal storage tests and the other the visuo-spatial storage tasks and all the concurrent processing tasks. This model (Model 5) had slightly better fit indexes than Model 3 and it showed not significant differences $\left(\Delta \chi^{2}=1.743\right.$, $p=.42)$.

Model 5 was also tested in the 6-years old subsample and didn't had good fit indexes (see Table 3).

\section{Figure 1}

Factor loading and factor covariance for the three-factor model (A) and Model 5 (B) for the data for 8-years old groups

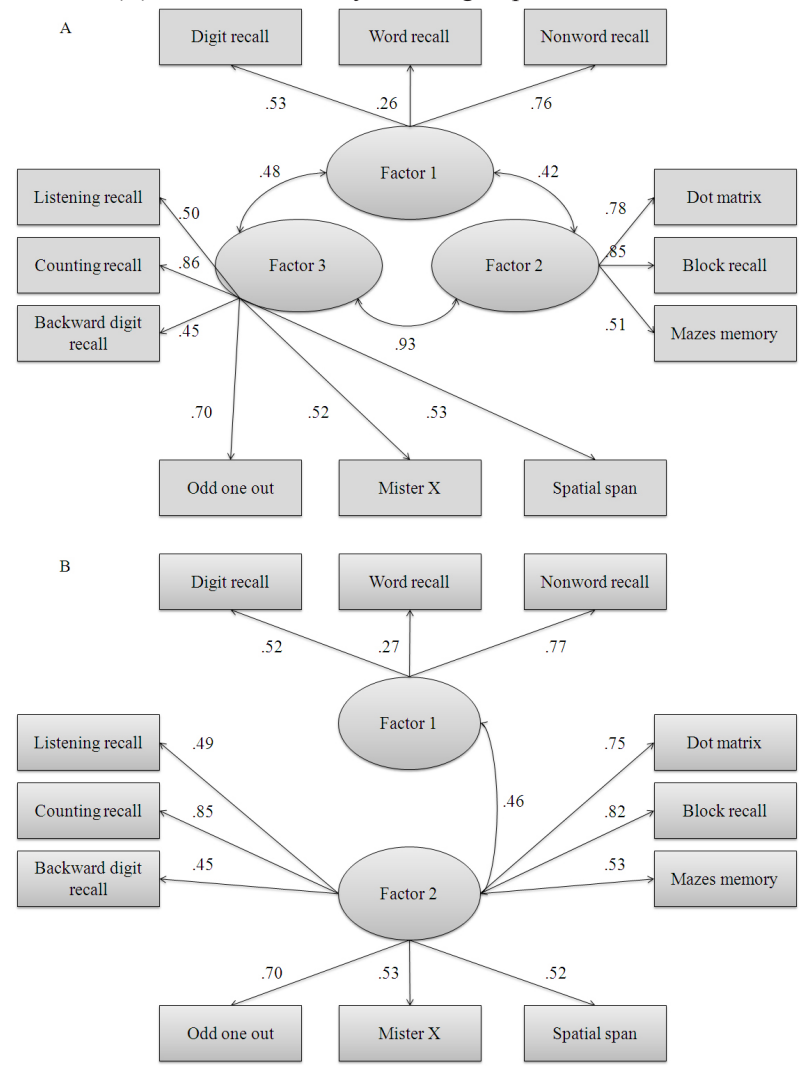

Figure 2

Factor loading and factor covariance for the four-factor model for the data for 11-years old groups

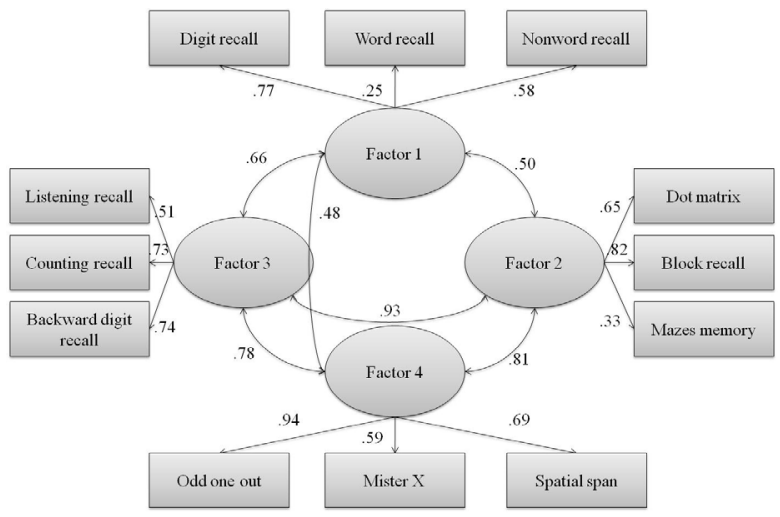

Figure 3

Factor loadings and factor covariances for the three-factor model (A) and four-factor model (B) for the data for all groups.

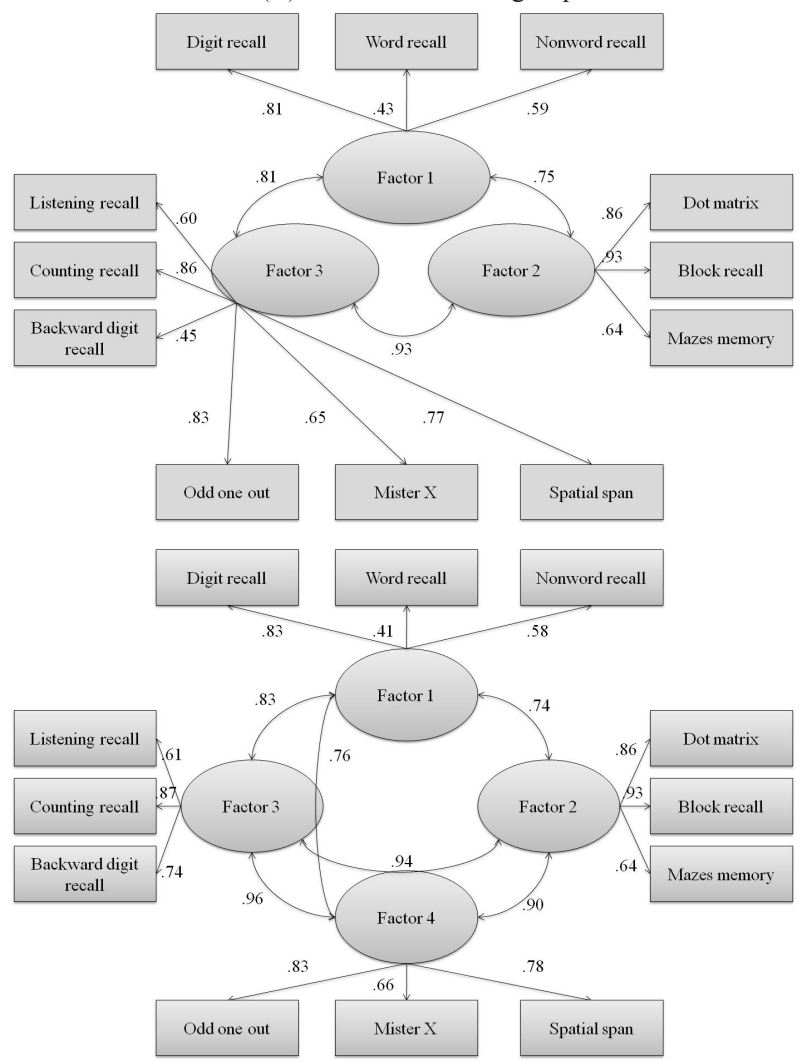

At 11-years old, the second, third, fourth, and fifth model showed good fit indexes. Among those models, the one that presented the best indexes was the four factors model $\left(\chi^{2}=46.786\right.$, $p=.523 ; C F I=1.000 ; T L I=1.000 ; R M S E A=.000)$. This model was significant different from Model $2\left(\Delta \chi^{2}=11.317, p\right.$ $=.045)$, Model $3\left(\Delta \chi^{2}=9.942, p=.019\right)$, and Model $5\left(\Delta \chi^{2}=\right.$ $13.960, p=.016)$. Table 3 shows the resulting fit indexes for the 11-years old group. The factor score weight values found are 
shown in Figure 2. Regarding the correlations among factors, the following significant and positive correlations were found: Factor 1 and Factor $2(r=.502, p=.014)$, Factor 1 and Factor 3 $(r=.663, p=.003)$, Factor 1 and Factor $4(r=.482, p=.020)$, Factor 2 and Factor $3(r=.739, p=.001)$, Factor 2 and Factor $4(r=.815, p=.001)$, and Factor 3 and Factor $4(r=.778, p$ $=.002)$.

The same analyses were conducted with the complete sample. Both Model 3 and Model 4 had good fit indexes (threefactor model: $\chi^{2}=67.413, p=.06 ; C F I=.986 ; T L I=.982$; $R M S E A=.042$; four-factor model: $\chi^{2}=60.815, p=.10 ; C F I$ $=.989 ; T L I=.985 ; R M S E A=.039)$ (see Table 3$)$, and significant difference between them weren't found $\left(\Delta \chi^{2}=6.598, p=\right.$ $.085)$. Figure 3 shows the resulting models.

\section{Discussion}

The aim of this study was to provide evidence regarding WM structure in children of different ages (6-, 8-, and 11-years old) and explore whether this system has a changing structure across childhood. For this purpose four models were originally tested. The first proposed model was a unitary and non-specific model. The second one was based on the idea of dissociation between the modality of the information being stored or processed by WM, resulting in a two factor model, verbal and visuospatial. The third model that was proposed included two low executive demand storage systems -a verbal and a visuo-spatial one- and a high executive demand system that includes both verbal and visuo-spatial processing tasks, inspired in Baddeley and Hitch's original model (1974). The last of the models proposed a division between storage and processing resources within each modality, which implies fractioning WM in four factors: a verbal short term memory factor, a verbal working memory factor, a visuo-spatial short term memory factor, and a visuo-spatial working memory factor (e.g. Alloway, Gathercole, Willis et al., 2004; Baddeley, Thomson, \& Buchanan, 1975; Baddeley \& Wilson, 1985; Conway et al., 2002; Gathercole \& Baddeley, 1989; Gathercole \& Hitch, 1993; Papagno, Valentine \& Baddeley, 1991; Papagno \& Vallar, 1992; Swanson, 1994; Unsworth \& Engle, 2007).

Correlation analysis supports the idea of a WM with a changing structure across childhood. At 6-years old the few significant associations that were found were low. The verbal low executive demand tasks didn't have an association with almost any task. Digit recall was the only one that showed associations with one verbal low executive demand task (Nonword recall), and two verbal high executive demand tasks (Counting recall and Backward digit recall). Furthermore, Listening recall didn't show any association with any other verbal task of the battery. On the other hand, Counting recall showed more associations with the visuo-spatial tasks than with the verbal ones. At 8-years old even if the correlations are slightly stronger than at 6-years-old, and more significant correlations were found (e.g. Listening recall and Counting recall), verbal low execu- tive demand tasks still didn't show associations with the rest of the tasks, and the verbal high executive demand tasks showed associations with both visuo-spatial low and high executive demand tasks rather than with the verbal low executive demand ones. Finally, at 11-years old, verbal low and high executive demand tasks are starting to show significant associations and the strength of the associations between the verbal high executive demand tasks and the visuo-spatial high executive demand tasks are becoming weaker.

The CFA conducted with the entire sample showed that two models (Model 3 and 4) had good fit indexes and we didn't found significant differences between them, suggesting that in different ages during childhood a different structure of WM could be observed. Regarding developmental variations, a different factorial solution was found for two age groups. For the 6-years old group none of the proposed models had good model fits, suggesting that at this early age WM structure is not clear yet. At the age of 8 , initially the model that had better fit indexes was the three factor model, suggesting that WM is composed by a verbal low executive demand storage factor, a visuo-spatial low executive demand storage factor, and a high executive demand processing factor. Nevertheless the high correlation observed between the factor that grouped the processing tasks and the visuo-spatial storage tasks lead to test a new two factor model: one factor included the verbal storage tasks and the second one the visuo-spatial tasks and the verbal and visuo-spatial processing tasks. This resulting model (Model 5) didn't had significant differences with the previous one (Model 3 ) and had better fit indexes. These results might indicate that at this age the visuo-spatial storage tasks (Dot matrix, Block recall, and Mazes memory) demand some executive resources. This suggest that at this age group we can't discuss a structuring of WM. At 11-years, even if the two, three, and four factor model had good fit indexes, the four factor model had the best fit indexes, which were significant different from the fit indexes of the other two models. According Model 4, WM is composed by a verbal low executive demand storage factor -VSTM-, a visuo-spatial low executive demand storage factor -VSSTM-, a verbal high executive demand processing factor -VWMand a visuo-spatial high executive demand processing factor -VSWM-. These last two factors suggest a fractioning within the domain-unspecific factor proposed in Models 3 regarding the modality of the information that is being processed, or a further specialization of processing resources according to modality.

Gathercole et al. (2004) tested a two factor model that separated VWM of VSWM, and a three factor model inspired on Baddeley and Hitch's original model, in a sample of children and adolescents form 6- to 15 -years old. They found that in all group ages WM had a three factor structure. The difference between the findings of the Gathercole et al. (2004) study and the present study may obey the fact that in our study visuo-spatial processing tasks were included, while the study conducted 
by Gathercole et al. (2004) only included verbal processing tasks to represent the CE. The tasks included in our analysis might influence and change the structure of the factors and their correlations.

Alloway et al. (2006) conducted a study in which using the same tests tested the three- and four-factor model proposed in the present study, along with a different three-factor model in which each storage factor and the processing factor shared their participation in the processing tests with the same modality as the storage factor. Thus, the factor that represented the $\mathrm{CE}$ grouped verbal and visuo-spatial processing tasks, the factor representing the PL grouped the verbal storing tests and the verbal processing ones, and the VSSP representing factor grouped both the visuo-spatial storing tests and the visuo-spatial processing tests. This model, which wasn't tested on the present study due to statistical limitations, is the one which had better fit indexes.

The results from this study suggest that WM structure changes among the tested group ages, showing a progressive differentiation and specialization within WM through childhood. Between the ages of 6 and 8 this memory system would initiate its structuring, since at 6 years-old non structure was found, and at 8 years-old the fact that more than one model had good fit indexes and didn't differentiate statistically from each other indicates an undefined structure. Near adolescence, a clear structure is found and indicates a complex structure within this memory system.

Further research could explore the cognitive processes contributing to structure changes in WM during childhood found on this study. On the other hand, research with adolescents, young adults, and adults could be done to explore whether the structure found at the age of 11 still holds or if it evolves to a different and more complex structure. Regarding WM structure and socioeconomic status, research in different socio-economic status should be conducted, since differences in WM development have been reported (Hackman \& Farah, 2009; Lipina, Martelli, Vuelta, Injoque-Ricle \& Colombo, 2004).

Even though different authors justified the sample sizes used in this study -n:p ratio- (Cattell, 1978; Gorsuch, 1983), this results should be considered as exploratory and future studies with bigger sample size should be conducted to confirm these results. Also, with a bigger sample size, the model that had better fit indexes in the study of Alloway et al. (2006) should be tested to establish whether it has better fit indexes than the models resulting from this study.

\section{References}

1. Ackerman, P. L., Beier, M. E. \& Boyle, M. O. (2005). Working Memory and Intelligence: The Same or Different Constructs? Psychological Bulletin, 131, 30-60. http:// dx.doi.org/10.1037/0033-2909.131.1.30

2. Adams, A. M. \& Gathercole, S. E. (2000). Limitations in working memory: implications for language development. International Journal of Language \& Comunication Disorders, 35, 95-116. http://dx.doi. org/10.1080/136828200247278

3. Alloway, T. \& Chiara Passolunghi, M. (2011). The relationship between working memory, IQ, and mathematical skills in children. Learning and Individual Differences, 21, 133-137. http://dx.doi.org/10.1016/j.lindif.2010.09.013

4. Alloway, T. P. (2007). Automated Working Memory Assessment. London: The Psychological Corporation.

5. Alloway, T. P., Gathercole, S. E., \& Pickering, S. J. (2006). Verbal and Visuospatial Short-Term and Working Memory in Children: Are They Separable? Child Development, 77, 1698-1716. http://dx.doi.org/10.1111/j.14678624.2006.00968.x

6. Alloway, T. P., Gathercole, S. E., Willis, C. \& Adams, A. M. (2004). A structural analysis of working memory and related cognitive skills in young children. Journal of Experimental Child Psychology, 87, 85-106. http://dx.doi. org/10.1016/j.jecp.2003.10.002

7. Anderson, J. R., Reder, L. M. \& Lebiere, C. (1996). Working memory: Activation limitations on retrieval. Cognitive Psychology, 30, 221-256. http://dx.doi.org/10.1006/ cogp.1996.0007

8. Arbuckle, J. L. (2003). AMOS 5.0. Chicago: SmallWaters.

9. Baddeley, A. D. (1986). Working memory. Oxford: Clarendon Press.

10. Baddeley, A. D. (1992). Working Memory. Science, 255, 556-559. http://dx.doi.org/10.1126/science.1736359

11. Baddeley, A. D. (1999a). Essentials of human memory. Hove, UK: Psychology Press.

12. Baddeley, A. D. (1999b). Memoria humana: Teoría y práctica. Madrid: McGraw-Hill/Interamericana de España.

13. Baddeley, A. D. (2000). The episodic buffer: a new component of working memory? Trends in Cognitive Sciences, 4, 417-423. http://dx.doi.org/10.1016/S1364$\underline{6613(00) 01538-2}$

14. Baddeley, A. D. (2007). Working Memory, thought, and action. Oxford: Oxford University Press. http://dx.doi. org/10.1093/acprof:oso/9780198528012.001.0001

15. Baddeley, A. D. \& Hitch, G. J. (1974). Working memory. In G. H. Bower (Ed.), The psychology of learning and motivation: Advances in research and theory (Vol. 8, pp. 47-90). New York: Academic Press.

16. Baddeley, A. D. \& Logie, R. H. (1999). Working Memory: The multiple-component model. In A. Miyake \& P. Shah (Eds.), Models of Working Memory (pp. 28-61). Cambridge: Cambridge University Press.

17. Baddeley, A. D. \& Wilson, B. (1985). Phonological coding and short-term memory in patients without speech. Journal of Memory and Language, 24, 490-502. http://dx.doi. org/10.1016/0749-596X(85)90041-5

18. Baddeley, A. D., Gathercole, S. E. \& Papagno, C. (1998). The phonological loop as a language learning device. 
Psychological Review, 105, 158-173. http://dx.doi. org/10.1037/0033-295X.105.1.158

19. Baddeley, A. D., Thomson, N. \& Buchanan, M. (1975). Word length and the structure of short-term memory. Journal of Verbal Learning and Verbal Behavior, 14, 575-589. http://dx.doi.org/10.1016/S0022-5371(75)80045-4

20. Bollen, K. A. (1990). Overall fit in covariance structure models: Two types of sample size effects. Psychological Bulletin, 107, 256-259. http://dx.doi.org/10.1037/0033$\underline{2909.107 .2 .256}$

21. Bull, R. \& Scerif, G. (2001). Executive functioning as a predictor of children's mathematics ability: Inhibition, task switching, and working memory. Developmental Neuropsychology, 19, 273-293. http://dx.doi.org/10.1207/ $\underline{\mathrm{S} 15326942 \mathrm{DN} 1903 \quad 3}$

22. Cain, K., Bryan, P. \& Oakhill, J. (2004). Children's reading comprehension ability: Concurrent prediction by working memory, verbal ability, and component skills. Journal of Educational Psychology, 96, 31-42. http://dx.doi. org/10.1037/0022-0663.96.1.31

23. Cattell, R. B. (1978). The scientific use of factor analysis. New York: Plenum. http://dx.doi.org/10.1007/978-1-46842262-7

24. Chuah, Y. M. L. \& Maybery, M. T. (1999). Verbal and spatial short-term memory: Two sources of developmental evidence consistent with common underlying processes. International Journal of Psychology, 34, 374-377. http://dx.doi. org/10.1080/002075999399710

25. Colom, R., Abad. F., Quiroga, M. A., Shih, P. C. \& FloresMendoza, C. (2008). Working memory and intelligence are highly related constructs but why? Intelligence, 36, 584606. http://dx.doi.org/10.1016/j.intell.2008.01.002

26. Colom, R., Flores-Mendoza, C. \& Rebollo, I. (2003). Working memory and intelligence. Personality and Individual Differences, 34, 33-39. http://dx.doi.org/10.1016/ $\underline{\mathrm{S} 0191-8869(02) 00023-5}$

27. Conway, A. R. A. \& Engle, R. W. (1994). Working memory and retrieval: A resource-dependent inhibition model. Journal of Experimental Psychology: General, 123, 354-373. http://dx.doi.org/10.1037/0096-3445.123.4.354

28. Conway, A. R. A., Cowan, N., Bunting, M. F., Therriault, D. J. \& Minkoff, S. R. B. (2002). A latent variable analysis of working memory capacity, short-term memory capacity, processing speed, and general fluid intelligence. Intelligence, 30, 163-183. http://dx.doi.org/10.1016/S01602896(01)00096-4

29. Conway, A. R. A., Moore, A. B. \& Kane, M. J. (2009). Recent trends in the cognitive neuroscience of working memory: A review of "The cognitive neuroscience of working memory". Cortex, 45, 262-268. http://dx.doi. org/10.1016/j.cortex.2008.05.006

30. Daneman, M. \& Carpenter, P. A. (1980). Individual differences in working memory and reading. Journal of Verbal
Learning and Verbal Behavior, 19, 450-466. http://dx.doi. org/10.1016/S0022-5371(80)90312-6

31. Daneman, M. \& Tardif, T. (1987). Working memory and reading skill reexamined. In M. Coltheart (Ed.), Attention and performance XII: The psychology of reading (pp. 491508). Hillsdale, NJ: Erlbaum.

32. Engel, P. M. J., Conway, A. R. A. \& Gathercole, S. E. (2010). Working memory and fluid intelligence in young children. Intelligence, 38, 552-561. http://dx.doi.org/10.1016/j. intell.2010.07.003

33. Engle, R. W. \& Kane, M. J. (2004). Executive attention, working memory capacity, and a two-factor theory of cognitive control. In B. Ross (Ed.), The psychology of learning and motivation (pp. 145-199). New York: Academic Press.

34. Engle, R. W., Tuholski, S. W., Laughlin, J. E. \& Conway, A. R. A. (1999). Working memory, short-term memory and general fluid intelligence: a latent variable approach. Journal of Experimental Psychology: General, 128, 309-331. http://dx.doi.org/10.1037/0096-3445.128.3.309

35. Friedman, N. P. \& Mikaye, A. (2004). The reading span test and its predictive power for reading comprehension ability. Journal of Memory and Language, 51, 136-158. http:// dx.doi.org/10.1016/j.jml.2004.03.008

36. Fürst, A. J. \& Hitch, G. J. (2000). Separate roles for executive and phonological components of working memory in mental arithmetic. Memory and Cognition, 28, 774-782. http://dx.doi.org/10.3758/BF03198412

37. Gathercole, S. E. \& Baddeley, A. D. (1989). Development of vocabulary in children and short-term phonological memory. Journal of Memory and Language, 28, 200-213. http://dx.doi.org/10.1016/0749-596X(89)90044-2

38. Gathercole, S. E. \& Baddeley, A. D. (1990). Phonological memory deficits in language disordered children: Is there a causal connection? Journal of Memory and Language, 29, 336-360. http://dx.doi.org/10.1016/0749-596X(90)90004-J

39. Gathercole, S. E. \& Hitch, G. J. (1993). Developmental changes in short-term memory: A revised working memory perspective. In A. Collins, S. E. Gathercole, M. A. Conway \& P. E. Morris (Eds.), Theories of Memory (pp. 189-210). Hove: Erlbaum.

40. Gathercole, S. E., Pickering, S. J., Ambridge, B. \& Wearing, H. (2004). The structure of working memory from 4 to 15 years of age. Developmental Psychology, 40, 177-190. http://dx.doi.org/10.1037/0012-1649.40.2.177

41. Gathercole, S. E., Willis, C., Emslie, H. \& Baddeley, A. D. (1992). Phonological memory and vocabulary development during the early school years: A longitudinal study. Developmental Psychology, 28, 887-898. http://dx.doi. org/10.1037/0012-1649.28.5.887

42. Gorsuch, R. L. (1983). Factor analysis (2nd ed.). Hillsdale, NJ: Erlbaum.

43. Hackman, D. A. \& Farah, M. A. (2009). Socioeconomic status and the developing brain. Trends in Cog- 
nitive Sciences, 13, 65-73. http://dx.doi.org/10.1016/j. tics.2008.11.003

44. Hair, F., Anderson, R. E., Tatham, R. L. \& Black, W. C. (1998). Multivariate data analysis with readings. New Jersey: Prentice Hall.

45. Harrington, D. (2008). Confirmatory Factor Analysis. Oxford: Oxford University Press. http://dx.doi.org/10.1093/ acprof:oso/9780195339888.001.0001

46. Hinson, J. M., Jameson, T. L. \& Whitney, P. (2003). Impulsive decision making and working memory. Journal of Experimental Psychology: Learning, Memory, and Cognition, 29, 298-306. http://dx.doi.org/10.1037/02787393.29.2.298

47. Hitch, G. J., Towse, J. N. \& Hutton, U. (2001). What limits children's working memory span? Theoretical accounts and applications for scholastic development. Journal of Experimental Psychology: General, 130, 184-198. http://dx.doi. org/10.1037/0096-3445.130.2.184

48. Hu, L. \& Bentler, P. M. (1999). Cutoff criteria for fit indexes in covariance structure analysis: Conventional criteria versus new alternatives. Structural Equation Modeling, 6, 1-55. http://dx.doi.org/10.1080/10705519909540118

49. Hulme, C., Thomson, N., Muir, C. \& Lawrence, A. (1984). Speech rate and the development of short term memory span. Journal of Experimental Child Psychology, 38, 241253. http://dx.doi.org/10.1016/0022-0965(84)90124-3

50. Injoque-Ricle, I., Calero, A., Alloway, T. P. \& Burin, D. I. (2011). Assessing Working Memory in Spanish-Speaking Children: Automated Working Memory Assessment Adaptation. Learning and Individual Differences, 21, 78-84. http://dx.doi.org/10.1016/j.lindif.2010.09.012

51. Just, M. A. \& Carpenter, P. A. (1992). A capacity theory of comprehension: Individual differences in working memory. Psychological Review, 99, 122-149. http://dx.doi. org/10.1037/0033-295X.99.1.122

52. Kane, M. J., Conway, A. R. A., Hambrick, D. Z. \& Engle, R. W. (2007). Variation in working memory capacity as variation in executive attention and control. In A. R. A. Conway, C. Jarrold, M. J. Kane, A. Miyake \& J. N. Towse (Eds.), Variation in working memory (pp. 21-48). New York: Oxford University Press.

53. Kane, M. J., Hambrick, D. Z., Tuholski, S. W., Wilhelm, O., Payne, T. W. \& Engle, R. W. (2004). The generality of working memory capacity: A latent-variable approach to verbal and visuo-spatial memory span and reasoning. Journal of Experimental Psychology: General, 133, 189-217. http://dx.doi.org/10.1037/0096-3445.133.2.189

54. Kane, M. J., Poole, B. J., Tuholski, S. W. \& Engle, R. W. (2006). Working Memory Capacity and the Top-Down Control of Visual Search: Exploring the Boundaries of "Executive Attention". Journal of Experimental Psychology: Learning, Memory, and Cognition, 32, 749-777. http:// dx.doi.org/10.1037/0278-7393.32.4.749
55. Kline, R. B. (1998). Principles and practice of structural equation modeling. New York: Guilford Press.

56. Kyllonen, P. C. \& Christal, R. E. (1990). Reasoning ability is (little more than) working memory capacity?! Intelligence, 14, 389-433. http://dx.doi.org/10.1016/S0160$\underline{\text { 2896(05)80012-1 }}$

57. Leather, C. V. Henry, L. A. (1994). Working Memory Span and Phonological Awareness Tasks as Predictors of Early Reading Ability. Journal of Experimental Child Psychology, 58, 88-111.

58. Lipina, S. J., Martelli, M. I., Vuelta, B. L., Injoque Ricle, I. \& Colombo, J. A. (2004). Pobreza y desempeño ejecutivo en alumnos preescolares de la Ciudad de Buenos Aires (República Argentina). Interdisciplinaria, 21, 153-193.

59. Logie, R. H. (1995). Visuo-spatial working memory. Hove: Erlbaum.

60. Logie, R. H. \& Pearson, D. G. (1997). The inner eye and the inner scribe of visuo-spatial working memory: Evidence from developmental fractionation. European Journal of Cognitive Psychology, 9, 241-257. http://dx.doi. org/10.1080/713752559

61. Logie, R. H., Gilhooly, K. J. \& Wynn, V. (1994). Counting on working memory in mental arithmetic. Memory \& Cognition, 22, 395-410. http://dx.doi.org/10.3758/BF03200866

62. Luciana, M., Conklin, H. M., Hooper, M. J. \& Yarger, R. S. (2005). The Development of nonverbal Working Memory and Executive Control Processes in Adolescents. Child Development, 76, 697-712. http://dx.doi.org/10.1111/ j.1467-8624.2005.00872.x

63. Oberauer, K., Süb, H. M., Schulze, R., Wilhelm, O. \& Wittmann, W. W. (2000). Working memory capacity facets of a cognitive ability construct. Personality and Individual Differences, 29, 1017-1045. http://dx.doi.org/10.1016/S01918869(99)00251-2

64. Owen, A. M., Doyon, J., Petrides, M. \& Evans, A. C. (1996). Planning and spatial working memory: A positron emission tomography study in humans. European Journal of Neuroscience, 8, 353-364. http://dx.doi. org/10.1111/j.1460-9568.1996.tb01219.x

65. Papagno, C. \& Vallar, G. (1992). Phonological short-term memory and the learning of novel words: The effect of phonological similarity and item length. Quarterly Journal of Experimental Psychology, 44, 47-67. http://dx.doi. org/10.1080/14640749208401283

66. Papagno, C., Valentine, T. \& Baddeley, A. D. (1991). Phonological short term memory and foreign-language vocabulary learning. Journal of Memory and Language, 30, 331347. http://dx.doi.org/10.1016/0749-596X(91)90040-Q

67. Phillips, L. H., Wynn, V., Gilhooly, K. J., Della Sala, S. \& Logie, R. H. (1999). The role of memory in the Tower of London task. Memory, 7, 209-231. http://dx.doi. org/10.1080/741944066

68. Redick, T. S., Heitz, R. P. \& Engle, R. W. (2007). Work- 
ing memory capacity and inhibition. In D. S. Gorfein \& C. M. MacLeod (Eds.), Inhibition in cognition (pp. 125-142). Washington, DC: American Psychological Association. http://dx.doi.org/10.1037/11587-007

69. Repovs, G. \& Baddeley, A. D. (2006). The multi-component model of working mwmory: Explorations in experimental cognitive psychology. Neuroscience, 139, 5-21. http://dx.doi.org/10.1016/j.neuroscience.2005.12.061

70. Reuhkala, M. (2001). Mathematical Skills in Ninth-graders: Relationship with visuo-spatial abilities and working memory. Educational Psychology, 21, 387-399. http:// dx.doi.org/10.1080/01443410120090786

71. Robert, C., Borella, E., Fagot, D., Lecerf, T. \& de Ribaupierre, A. (2009). Working memory and inhibitory control across the life span: Intrusion errors in the Reading span test. Memory and Cognition, 37, 336-345. http://dx.doi. org/10.3758/MC.37.3.336

72. Rosen, V. M. \& Engle, R. W. (1996). Working memory capacity and suppression. Journal of Memory and Language, 39, 418-416. http://dx.doi.org/10.1006/jmla.1998.2590

73. Schmiedek, F., Oberauer, K., Wilhelm, O. Süß, H. M. \& Wittmann, W. W. (2007). Individual differences of reaction time distributions and their relations to working memory and intelligence. Journal of Experimental Psychology: General, 136, 414-429. http://dx.doi.org/10.1037/00963445.136.3.414

74. Schumacker, R. E. \& Lomax, R. G. (1996). A beginner guide to structural equation modeling. Mahwah: Erlbaum.

75. Shah, P. \& Miyake, A. (1999). Models of Working Memory: An Introduction. In A. Miyake \& P. Shah (Eds.), Models of Working Memory (pp. 1-27). Cambridge: Cambridge University Press.

76. Süb, H. M., Oberauer, K., Wittmann, W. W., Wilhelm, O. \& Schulze, R. (2002). Working-memory capacity explains reasoning ability - and a little bit more. Intelligence, 30, 261288. http://dx.doi.org/10.1016/S0160-2896(01)00100-3
77. Swanson, H. L. (1994). Short-term memory and working memory: Do both contribute to our understanding of academic achievement in children and adults with learning disabilities? Journal of Learning Disabilities, 27, 34-50. http://dx.doi.org/10.1177/002221949402700107

78. Swanson, H. L. (2008). Working memory and intelligence in children: What develops? Journal of Educational Psychology, 100, 581-602. http://dx.doi.org/10.1037/0022$\underline{0663.100 .3 .581}$

79. Swanson, H. L. \& Howell, M. (2001). Working memory, short-term memory, and speech rate as predictors of children's reading performance at different ages. Journal of Educational Psychology, 93, 720-734. http://dx.doi. org/10.1037/0022-0663.93.4.720

80. Tillman, C. M., Nyberg, L. \& Bohlin, G. (2008). Working memory components and intelligence in children. Intelligence, 36, 394-402. http://dx.doi.org/10.1016/j. intell.2007.10.001

81. Unsworth, N. \& Engle, R. W. (2007). The nature of individual differences in working memory capacity: Active maintenance in primary memory and controlled search from secondary memory. Psychological Review, 114, 104-132. http://dx.doi.org/10.1037/0033-295X.114.1.104

82. Unsworth, N., Redick, T. S., Heitz, R. P., Broadway, J. M. \& Engle, R. W. (2009). Complex working memory span tasks and higher-order cognition: A latent-variable analysis of the relationship between processing and storage. Memory, 17, 635-654. http://dx.doi.org/10.1080/09658210902998047

Received 18 August 2011 Received in revised form 27 January 2012 Accepted 19 April 2012 